\title{
PENUNDAAN KEWAJIBAN PEMBAYARAN UTANG DALAM KEPAILITAN (ANALISIS TERHADAP PUTUSAN PENGADILAN NIAGA NOMOR: 20/ PAILIT/2011/PN.NIAGA.SBY)
}

\author{
Oleh:
}

I Wayan Wesna Astara*

\begin{abstract}
The insolvent Debtor (PT Dwimas Andalan Bali) filed for insolvency by the Creditors (PT. Karsa Industama Mandiri) did not use his rights to submit a Delay for Debt Payment Obligations (DDPO) due to creditors have been in default and there has been an allegation of fraud in the insolvency proceedings becomes a phenomenon in the world of tourism business in Indonesia. In fact that the Debtor filed for insolvency has executed reconciliation with the other creditors, however there was no reconciliation with PT. Karsa Industama Mandiri. Therefore, the debtor has lost his opportunity to prevent insolvency through the Agency of Delay for Debt Payment Obligations (DDPO). Thus, the problems of this thesis are: what are the efforts of DDPO in insolvency mechanism? And how is the legal protection for debtor in insolvency proceedings.

This research applied normative legal research method with the historical approach, legislative approach, and conceptual approach. Furthermore, the source of primary legal materials and secondary legal materials were analyzed through the measures of description, interpretation, systematization, evaluation and argumentation.

The results of the research showed that the debtor (PT Dwimas Andalan Bali) as the Respondent of Insolvency has filed rebuttal that the Applicant of Insolvency has committed defaults by applying the doctrine of excptio non adimpleti cordractus and the Applicant of Insolvency (PT Industama Karsa Mandiri) was alleged of committing frauds and forgery. Therefore the insolvent debtor who should filed for insolvency to DDPO did not execute it, instead he executed reconciliation with the other creditors unless the Applicant of Insolvency. In this case, the DDPO Agency was not meaningful to the debtor and the Debtor of Insolvency reported the Applicant of Insolvency to the Regional Police of Bali. Related to the legal protection of debtor under the Law of Insolvency and DDPO No. 37 of 2004, there has been no principle reflected to provide equal protection for all relevant parties concerned against one's or company's insolvency.
\end{abstract}

Keywords. Debtor Insolvency, DDPO and Legal Protection

I PENDAHULUAN

\subsection{Latar Belakang Masalah}

Kehadiran dunia bisnis perhotelan dari PT Dimas Andalan Bali selanjutnya disebut (PT. DAB) sebagai perusahaan pengelola

* Mahasiswa Magister Ilmu Hukum Unud
Bali Kuta Residen selanjutnya disebut BKR, dalam kegiatan usahanya yang baru dalam proses pembangunan, tidak sertamerta memperoleh suatu keuntungan seuai dengan tujuan perusahaan. Pada dasarnya kegiatan perusahaan pada umumnya dijalankan dengan tujuan untuk memperoleh 
keuntungan yang maksimal sesuai dengan pertumbuhan perusahaan dalam jangka panjang. Namun PT DAB dimohonkan pailit oleh PT Karsa Industama Mandiri (PT. KIM) ke pengadilan niaga Surabaya dan mengabulkan permohonan pemohon Pailit untuk seluruhnya. ${ }^{1}$

Dalam poses perkara Kepailitan yang diajukan ke pengadilan dapat dilawan atau ditangkis yang lazim disebut dengan eksepsi. Kesempatan menangkis itu diberikan setelah gugatan atau permohonan kepailitan dibacakan di persidangan. Sudah tentu dalam perkara kepailitan dan perkara Penundaan Kewajiban Pembayaran Utang yang selanjutnya disebut (PKPU), pihak termohon diberikan kesempatan untuk mengajukan perlawanan. Dalam praktik beracara di pengadilan Niaga, terhadap permohonan pailit dapat ditangkis atau dilawan dengan PKPU. Artinya dalam hal orang perorangan atau badan hukum hendak dipailitkan, debitor dapat mengajukan eksepsi terhadap permohonqan pailit agar jangan dipailitkan. ${ }^{2}$

Aturan Kepailitan telah memberikan ruang untuk debitur yang dimohonkan pailit yang mempunyai kesempatan untuk melakukan pengajuan PKPU demi untuk menunda terjadinya kepailitan sekaligus mengadakan restrukturisasi utangutangnya kepada kreditor. Ketentuan tentang diberikan perlindungan kepada debitor untuk mengajukan PKPU tertuang dalam (Pasal 222, Ayat 2 UU Kepailitan

Salinan Putusan Nomor: 20/Pailit/2011/PN. Niaga. Sby, passim.

Syamsudin M, Sinaga,2012, Hukum Kepailitan Indonesia, PT Tata Nusa, Jakarta, hlm.281. dan PKPU). Dengan demikian bahwa penundaan kewajiban pembayaran utang (surseance van betaling) yang dimohonkan oleh debitur melalui advokat ke pengadilan niaga tersebut pada umumnya dengan tujuan untuk mengajukan rencana perdamaian yang meliputi pembayaran seluruh atau sebagian uangnya kepada kreditur konkuren, agar tidak terjadi kepailitan. Namun hal tersebut tidak dilakukan oleh debitor dengan alasan kreditor telah melakukan wanprestasi sesuai dengan Surat Perintah Kerja (SPK) No. 085/SPK/BKR-MEP/VIII/2008. Selain itu, juga karena alasan Termohon, tidak mengajukan PKPU, karena Pemohon PT.KIM ada dugaan telah melakukan keterangan palsu (penipuan-penipuan) pada saat pengajuan proses pailit, sehingga PT KIM dilaporkan ke Polda Bali. Dengan demikian, manakala debitur dimohonkan pailit oleh kreditur sesungguhnya Debitor (PT.DAB) masih memiliki upaya untuk keluar dari status pailit, tanpa melihat apakah kreditor wanprestasi atau dalam proses kepailitan ada dugaan pemalsuan suratsurat atau penipuan-penipuan, karena dalam pemalsuan surat-surat masuk dalam ranah hukum pidana. Debitor yang dimohonkan pailit tangkisannya menurut hukum kepailitan adalah dengan mengajukan permohonan PKPU. Melalui mekanisme PKPU, debitor mempunyai kesempatan untuk merestrukturisasi utangnya, sebagai upaya mencegah kepailitan. Menghadapi permohonan kepailitan dari krediturnya, debitur pada waktu yang sama dapat mengajukan penangguhan pembayaran sesuai ketentuan pasal 246 UU Kepailitan. Penangguhan pembayaran ini sebagai 
perlawanan atas permohonan kepailitan yang diajukan oleh krediturnya. Permohonan Penundaan Kewajiba pembayaran dari debitur tersebut diajukan pada waktu menjawab permohonan kepailitan. ${ }^{3}$

Debitor yang dimohonkan pailit, secara hukum memperoleh Perlindungan hukum terhadap kepailitan tercantum pada pasal 229 ayat (3) dan (4) diatur tentang kedudukannya yang lebih dipentingkan adalah terhadap permohonan PKPU daripada permohonan pernyataan Pailit. Dalam pasal ini disebutkan bahwa apabila permohonan PKPU dan kepailitan bersamaa, maka yang diutamakan diperika lebih dulu adalah PKPU.

Dalam putusan pailit Nomor. 20/ Pailit/2011/PN.Niaga.Sby;Pemohon disangkal telah melakukan wanprestasi terhadap Termohon sehingga ditangkis terjadinya kondisi Exceptio Non Adimpleti Contractus, yaitu dalam doktrin ini pihak pemohon dan termohon sama-sama mimiliki utang yang harus dilaksanakan dalam bentuk prestasi, apabila pemohon tidak melaksanakan prestasi, pihak termohon pailit dapat pula tidak melaksanakan prestasi. ${ }^{4}$ Debitor dalam cara mencegah Pailit, salah satunya adalah mengajukan Exceptio Non Adimpleti Contractus. Makna Eksepsi ini adalah bahwa pemohonan pailit juga mempunyai utang kepada termohon pailit. Jadi antara pemohon dan termohon pailit saling mempunyai utang piutang.

Anton Suyatno, 2012, Pemanfaatan Penundaan Kewajiban Pembayaran Utang, sebagai Upaya mencegah Kepailitan, Kencana, Jakarta, hlm.68.

4 Munir Fuady,2001, Hukum Kontrak (Dari sudut Pandang Hukum Bisnis), PT Citra Aditya Bakti, Bandung, hlm.90.
Dalam keadaan yang demikian maka kedua utang itu diperjumpakan (set-off). Dalam konteks yang demikian, termohon Pailit dapat mengajukan eksepsi dengan dalil bahwa pemohon pailit juga mempunyai utang kepada termohon pailit. Oleh karena itu perlu diperjumpakan utang tersebut. ${ }^{5}$

Demikian pula adanya kesepakatan baru, antara Termohon (PT.DAB) dengan pemohon (PT KIM) tertanggal 3 Juli 2010, yang membatalkan atau mencabut kesefakatan yang dibuat rentang 2008sampai dengan sebelum tanggal 3 Juli 2010.

Demikian pula halnya tentang Somasi yang dilayangkan oleh Pemohon pailit kepada termohon pailit sebelum diajukan permohonan kepailitan, memberikan peluang kepada Termohon pailit untuk membatalkan perjanjian borongan "Surat Perintah Kerja No: 085/SPK/BKR-MRP/VIII/2008, tanggal 5 Agustus 2008, ke pengadilan Negeri Denpasar.

Menurut Hadi Shuban, utang dalam Kepailitan dan PKPU sebelum kreditor mengajukan permohonan pailit terhadap debitor, syarat material yang harus dipenuhi oleh kreditor adalah adanya utang yang telah jatuh tempo yang tidak dibayar yang dapat ditagih dan debitor memiliki setidak tidaknya dua kreditor. Dengan jelas disebutkan dalam hukum kepailitan bahwa konsep utang dimaksud mengacu kewajiban di bidang bisnis atau setidak-tidaknya menyangkut prihal kekayaan harta benda dengan berlandaskan pada ketidakmampuan debitor untuk membayar kewajibannya.

Syamsudin M.Sinaga,2012, Hukum Kepailitan Indonesia,PT Tana Nusa, Jakarta, hlm.111. 
Untuk dapat dinyatakan pailit, seorang debitor harus memenuhi syarat sebagai berikut: a) Debitor mempunyai dua atau lebih kreditur; Tidak membayar sedikitnya satu utang jatuh waktu dan dapat ditagih; c) Atas permohonannya sendiri maupun atas permintaan seorang atau lebih kreditornya. Ketentuan ini hanya mengacu kepada kewajiban dibidang bisnis atau seteidak-tidaknya menyangkut prihal kekayaan harta benda dengan berlandaskan ketidakmampuan debitor untuk membayar kewajibannya kepada kreditor, bukan ketidakmauan karena alasan wanprestasi dan dugaan pemalsuan surat-surat, penipuan dan penggelapan atau kompeksitas atau perkara tidak sumir. Ketentuan ini tidak menyinggung kebangkrutan sebagai alasan debitur tidak membayar utang, mengingat pengertian "tidak membayar" dapat berarti tidak dapat membayar atau tidak mau membayar. ${ }^{6}$ Dalam penjelasan Pasal 2 Ayat (1), tidak dijelaskan mengenai maksud dari frase "tidak membayar utang" tersebut, sehingga dengan demikian ketentuan pasal 2, Ayat (1) mengandung norma kabur yang dapat menimbulkan kerancuan dalam menilai keadaan debitur mana yang seharusnya diajukan permohonan pernyataan pailit. ${ }^{7}$

Man S. Sastrawidjaja, 2010, Hukum Kepailitan dan Penundaan kewajiban pembayaran Utang, Alumni, Bandung, hlm.80.

Lihat Pula, Samuil Kurniawan Nyoman, 2013, "Kepailitan Yang bermula dari keadaan Exceptio inadimpleti Contractus (Alanisis terhadap Putusan Pernyataan pailit dalam Perspektif Hukum Perjanjian dan Kepailitan)", Dalam Tesis yang belum diterbitkan, Denpasar, Program Studi Magister (S2) ilmu hukum Program Pasca Sarjana Universitas Udayana, Denpasar, hlm.3.
Berkaitan dengan hal tersebut di atas, manakala debitur dimohonkan pailit oleh kreditornya, Debitor dapat mengajukan penundaan kewajiban pembayaran utang ke pengadilan niaga, apabila tidak dapat atau memperkirakan bahwa ia tidak akan dapat melanjutkan membayar utang-utangnya yang sudah jatuh waktu sebagai reaksi atas permohonan pailit yang diajukan oleh (para) kreditornya (Pasal 222, Ayat 2 UU $\mathrm{K}$ dan PKPU). Dengan demikian bahwa penundaan kewajiban pembayaran utang (surseance van betaling) yang dimohonkan oleh debitur melalui advokat ke pengadilan niaga tersebut pada umumnya dengan tujuan untuk mengajukan rencana perdamaian yang meliputi pembayaran seluruh atau sebagian uangnya kepada krediturkonkuren, agar tidak terjadi kepailitan. Oleh karena itu dengan pertimbangan bahwa mencegah terjadinya kepailitan dapat menguntungkan banyak pihak, baik karyawan, rantai usaha (business chain), pemegang saham (shareholder) maupun kreditur yang akan terbayar utangnya, maka PKPU ditempatkan pada ranking pertama dalam penetapan putusan apabila beberapa perkara diajukan secara bersama-sama. Hal ini berarti bahwa secara imperatif pengadilan harus mengabulkan penundaan "sementara" kewajiban pembayaran utang (vide pasal 225 ayat 2 UU K dan PKPU). ${ }^{8}$ Dalam PKPU, seorang debitor yang beritikad baik, masih memiliki hak untuk mengajukan PKPU, sebelum diucapkan Putusan Pernyataan Pailit oleh Majelis hakim.

Anton Suyatno, R, 2012, op.cit., hlm.5. 
Debitor pailit kehilangan haknya untuk melakukan PKPU manakala Debitor dipailitkan walupun ia menangkis dengan wanprestasi dan dugaan penipuan-penipuan.

\section{Rumusan Masalah.}

Berdasarkan uraian dan latar belakang tersebut di atas, dapat dirumuskan permasalahan sebagai berikut:

a. Bagaimana upaya PKPU dalam mekanisme kepailitan?

b. Bagaimana perlindungan hukum debitor dalam proses kepailitan?

\section{Tujuan penelitian:}

a) Untuk mengenalisis Upaya hukum debitor yang dimohonkan pailit oleh kreditor serta debitor yang tidak mengajukan Penundaan Kewajiban Pembayaran Utang; b) Mengenalis, memahami dan mendiskripsikan perlindungan hukum debitor dalam proses kepailitan.

\section{Metode Penelitian.}

Penelitian ini menggunakan metode penelitian hukum normative dengan pendekatan historis, pendekatan perundangundangan (statute approach), pendekatan konseptual (Conceptual approach), dan pendekatan analisis selanjutnya analisis yang dilakukan dengan deskripsi dan evaluasi analisis.

\section{HASIL DAN PEMBAHASAN.}

\subsection{Upaya PKPU Dalam Proses Kepailitan.}

Pada kasus posisi bahwa PT Karsa Industama Mandiri (Pemohon Pailit) dengan PT Dwimas Andalan Bali pengelola Bali Kuta Residen (Termohon Pailit) yang dikabulkan oleh Pengadilan Niaga Surabaya dengan putusan Nomor: 20/Pailit/2011/ PN. Niaga. Sby. Dalam proses kepailitan adanya manfaat PKPU sebagau upaya dalam mencegah untuk terlaksananya kepailitan adalah suatu hak yang diberikan kepada debitor untuk mengajukan PKPU. UndangUndang kepailitan dan PKPU Nomor: 37 Tahun 2004, telah memberikan ruang untuk mencegah terjadinya kepailitan asalkan debitor mempunyai itikad baik dalam proses untuk mengajukan PKPU. Debitor tidak melakukan PKPU, karena kreditor (PT KIM) diduga oleh Termohon Pailit telah melakukan wanprestasi dan penipuanpenipuan. Atas dasar itu, Termohon pailit tetap pada pendiriannya untuk melakukan upaya hukum kasasi dan Peninjauan Kembali. Selain itu, Termohon Pailit telah mengajukan perdamaian terhadap Kreditor-kreditor lainnya. Namun dalam pertimbangan Hakim, Termohon keliru dalam mengajukan Perdamaian terhadap kreditot-kreditornya dalam proses kepailitan, tidak ada perdamaian yang dapat dilakukan sebelum ada putusan, yang dimungkinkan adalah pihak Termohon untuk menghindari putusan Pailit, lalu pada kesempatan pertama mengajukan penawaran perdamaian dengan cara mengajukan PKPU, dengan prinsip bahwa penawaran perdamaian ditujukan kepada/untuk seluruh kreditor, dan bukan hanya kreditor yang dicantumkan namaya dalam surat permohonan pernyataan pailit. ${ }^{9}$ Pendapat majelis hakim Pengadilan Niga Surabaya ini berkaitan dengan Termohon tidak ada utang yang jatuh waktu KL-1 dan

Putusan Pailit Nomor 20/Pailit/2011/PN.Niaga.Sby, hlm.38. 
KL-II dengan Termohon, namun bila melihat pada kwitansi yang dibuat oleh KL-I, maka tampak pembayaran utang Termohon dilakukan saat proses Permohonan pailit ini sedang berlangsung, dan kesepakatan damai antara Termohon dengan KL-II dilaksanakan juga setelah proses kepailitan itu berlangsung. ${ }^{10}$

Menurut Syamsudin M. Sinaga, alasan untuk mencegah kepailitan adalah dengan mengajukan permohonan PKPU, sebagai jawaban, tanggapan, tangkisan atau counter terhadap permohonan pailit. ${ }^{11}$ Dengan demikian, menangkis kepailitan berupa pengajuan Penundaan kewajiban pembayaran Utang (PKPU) merupakan salah satu solusi dalam kepailitan dengan melakukan restrukturisasi utang. ${ }^{12}$

PKPU dalam UU Kepailitan belum memberikan kesempatan yang luas bagi debitor untuk memperbaiki kinerja perusahaan. Hal ini dapat dilihat dalam pemberian waktu yang relative singkat bagi debitor untuk melakukan perbaikan bagi perusahaannya, ${ }^{13}$ dominasi kreditor dalam menentukan rencana perdamaian, ${ }^{14}$ dan adanya keterbatasan kewenangan yang dimiliki oleh debitor untuk terus mengelola perusahaan yang harus dilakukannya bersama dengan pengurus. ${ }^{15}$

$10 \quad$ Ibid.

11 Syamsudin M. Sinaga, 2012, Hukum Kepailitan Indonesia, PT, Tatanusa, Jakarta, hlm.111.

12 Suapsti darmawan Ni Ketut (Dkk), Op. Cit., hlm.3.

13 Pasal 228 ayat (6) Undang-Undang Nomor 37 tahun 2004.

14 Pasal 281 Undang-Undang Nomor 37 tahun 2004.

15 Pasal 240 Undang-Undang Nomor 37 Tahun 2004.
Lembaga PKPU menjadi tidak bermakna dalam penyelesaian utang, diakibatkan karena kasus kepailitan yang dimohonkan oleh kreditor mengandung wanprestasi yang complicated (tidak sederhana), bahkan ada dugaan-dugaan mengandung penipuan-penipuan dalam penyelesaian borongan mekanikal dan elektrikal. Oleh karena itu, pihak Termohon (Debitor) ${ }^{16}$ tidak mengajukan perdamaian, sehingga Hakim Pengawas telah menetapkan Pailit dalam keadaan Insolvensi.

Apabila debitor melakukan PKPU, akibat hukum dalam PKPU adalah debitor akan kehilangan independensinya. Berbeda dengan proses kepailitan di mana pihak debitor pailit sama sekali tidak berwenang untuk mengurus harta bendanya dan kewenangan tersebut di ambil alih oleh pihak curator, tetapi dakam hal PKPU, debitor masih tetap berwenang untuk mengurus harta pailit. Bahkan, banyak hal, inisiatif untuk mengurus harta, seperti untuk meminjam uang , mengalihkan harta, dan sebagainya tetap berada di tangan pihak debitor. Malahan juga usaha debitor tetap berjalan.

Dalam Putusan Mahkamah Agung RI, Nomor 103 PK/ Pdt.Sus-Pailit/2013, memeriksa Perkara Perdata khusus permohonan pernyataan pailit pada pemeriksaan peninjauan kembali telah memutuskan sebagai berikut dalam perkara antara, Kepala Kepolisian Daerah Bali Cq. Direktur Reserse Kriminal Umum(Dit Reskrimum) Polda Bali, sebgai Pemohon Peninjauan Kembali dahulu turut Terlawan terhadap PT Karsa Industama Mandiri, sebagai Termohon Peninjauan Kembali dahulu Pelawan; dan PT Dwimandalan Bali (dalam pailit) sebagai turut Termohon peninjauan Kembali dahulu Terlawan. Bahwa dalam rapat kreditur pihak Terlawan tidak mengajukan rencana perdamaian, sehingga hakim pengawas telah menetapkan Harta Debitor pailit dalam keadaan Insolvensi, sesuai dengan penetapan Hakim Pengawas per-tanggal 30 September 2011 (bukti P-3), hlm.2. 
Hanya saja dalam bertindak, khususnya yang menyangkut dengan kepengurusan atau pemindahan hak atas harta kekayaannya , pihak debitor tidak lagi independen seperti sebelum penundaan kewajiban pembayaran utang. Sebab dalam bertindak tersebut, pihak debitor harus selalu didampingi oleh pihak pengurus. Dapat dikatakan bahwa antara pihak pengurus dan pihak debitor bertindak sebagai "kembar siam" atau dwitunggal.

Dalam hal kasus kepailitan Nomor 20/ Pailit/2011/PN.Niaga. Sby, sebelum kreditor (PT. Karsa Industama Mandiri) mengajukan permohonan pailit ke debitor (PT Dwimas Andalan Bali), supaya mengedepankan asas keadilan dalam menyelesaikan persoalan utang-piutangnya dengan debitor sebelum memutus untuk mempergunakan pranata kepailitan. ${ }^{17}$

Bentangan tentang teori keadilan yang dikaitkan dengan konsepsi hukum memang tidak tunggal. John Rawls menyampaikan bahwa peran keadilan sebagai kebajikan utama dalam institusi social. Sebagaimana kebenaran dalam system pemikiran. Demikian tentang keadilan, bisa saja ketika dibuat suatu Undang-undang dan disahkan saat itu dianggap benar, setelah berjalannya waktu terjadi perubahan pemikiran karena ada beberapa pasal yang tidak sesuai dengan perkembangan ekonomi, social dan yuridis serta perkembangan pemikiran masyarakat. Oleh karena itu semestinya direformasi atau dihapuskan jika tidak adil. ${ }^{18}$ Berdasarkan

Supasti Darmawan Ni Ketut, dkk, op.cit., hlm.41. John Rawls, 2006, A Theory of Justice, Teori keadilan, Dasar-dasar Filsafat Politik Untuk Mewujudkan Kesejahtraan Sosial dalam Negara, Yogyakarta, Pustaka pelajar, hlm.3-4. teori hukum alam, hakekat hukum adalah adil, sehingga hukum itu haruslah adil. Keadilan adalah suatu keadaan yang mencerminkan adanya keserasian antara hukum yang dicita-citakan dengan hukum yang berlaku. ${ }^{19}$ Keadilan sendiri merupakan salah satu tujuan hukum yang utama, selain kapastian hukum dan juga kemanfaatan. ${ }^{20}$

Menurut Siti Anisah persyaratan permohonan Pernyataan Pailit memudahkan pailitnya debitor. ${ }^{21}$ Perubahan terhadap pernyataan pailit dapat dilihat dari Faillissmentsverordening sampai dengan dengan UU No. 37 Tahun 2004. Terjadinya kekaburan norma karena substansi pasalpasal yang tidak tegas, dan terjadinya multitafsir yang berkaitan dengan permohonan pailit. Perubahan perubahan itu dapat dilihat dari pengertian utang, pengertian berhenti membayar, jatuh tempo dan dapat ditagih, kreditor dan debitor yang mengajukan permohonan pernyataan pailit; serta pembuktian sederhana sebagai dasar putusan pernyataan pailit. $^{22}$ Aturan tidak pantas menjadi sebuah hukum, apabila tidak adil. $^{23}$

Dalam UU Kepailitan dan PKPU Nomor 37 Tahun 2004, kreditor dapat pula menggunakan mekanisme PKPU terlebih dahulu sebelum mengambil tindakan hukum

20 Dardji Darmodiharjo dan Shidarta, 2004, Pokok-pokok Filsafat Hukum: Apa dan Bagaimana Filsafat Hukum Indonesia, PT Gramedia Pustaka Utama, Jakarta, hlm.154.

21 Siti Anisah, 2008, Perlindungan Kepentingan Kreditor dan Debitor Dalam Hukum Kepailitan di Indonesia, Total Media, Yogyakarta, hlm.43.

22 Ibid.

23 Bernarrd L. Tanya, Dkk, 2010, Teori Hukum Strategi Trrtib manusia Lintas Ruang dan generasi, Genta Publising, Yogyakarta, hlm.130. 
mengajukan permohonan pernyataan pailit bagi debitornya. ${ }^{24}$ Permohonan pailit yang diajukan oleh kreditor PT Karsa Industama Mandiri kepada Debitor PT Dwimas Andalan Bali, bahwa pihak Termohon tidak memiliki utang yang jatuh tempo dan dapat ditagih oleh pihak pemohon, sebaliknya pihak pemohon telah melakukan wanprestasi dan penipuanpenipuanterhadappihaktermohon; karenanya pihak Termohon mengajukan exception non adimpleti contractus. ${ }^{25}$ Menurut M Sinaga mantan hakim Niaga, makna exception non adimpleti contractus bahwa pemohon pailit juga mempunyai utang kepada termohon pailit. Jadi antara pemohon dan termohon pailit saling mempunyai utang piutang. Dalam keadaan yang demikian maka kedua utang itu diperjumpakan (set-off). Dalam konteks yang demikian, termohon pailit dapat mengajukan eksepsi dengan dalil bahwa pemohon pailit juga mempunyai utang kepada termohon pailit, sehinnga perlu diperjumpakan utang tersebut. ${ }^{26}$ Perjumpaan utang atau kompensasi (set-off) adalah suatu peristiwa hukum yang terjadi demi hukum di antara orang yang mempunyai utang maupun piutang dengan Debitor Pailit sebelum putusan pailit diucapkan. Perjumpaan utang terjadi demi hukum sesuai dengan asas Ipso Iure Compensatur. ${ }^{27}$

Dalam proses kepailitan antara Pemohon (PT Karsa Industama Mandiri) melawan PT Dwimas Andalan Bali

$24 \quad$ Ibid

25 Jawaban Termohon dalam Putusan No.20/Pailit/2011/ PN.Niaga.Sbya, hlm.8.

26 Syamsudin M.Sinaga,2012, Hukum Kepailitan Indonesia, PT. Tatanusa, Jakarta, hlm.111.

Ibid., hlm.121.
(Termohon), adanya selisih pendapat tentang pelaksanaan kontrak kerja, yaitu pemohon telah melakukan wanprestasi dan dugaan penipuan-penipuan. Menurut Termohon, bahwa sama sekali tidak mempunyai kewajiban yang jatuh tempo dan dapat ditagih oleh pihak pemohon, karena hingga saat ini, pihak pemohon telah lalai melakukan kewajibannya terhadap pihak Termohon sehingga saat ini kewajiban pihak Termohon sehingga saat ini kewajiban pihak Termohon belum terbit (secara sederhana dapat dikatakan bahwa tidak ada utang/kewajiban yang jatuh tempo dan dapat ditagih) ${ }^{28}$

Dalam analisis ini dapat dipergunakan teori pernyataan, apa yang dinyatakan itulah yang obyektif dan berlaku dengan kata lain dalam suatu perjanjian sehingga apa yang dikehendaki dan dinyatakan itu yang berlaku. ${ }^{29}$ Menurut Termohon Palit (PT DAB) berdasarkan Surat Perintah Kerja (SPK) No. 085/SPK/BKR-MEP/VIII/2008 tertanggal 5 Agustus 2008. Bahwa menurut Termohon, Pemohon dalam mengerjakan pekerjaan telah menurunkan spesifikasi barang yang telah disefakati dalam Bill of Quantity (BQ) tanpa seizing ataupun sepengetahuan Termohon. ${ }^{30}$

\subsection{Perlindungan Hukum Debitor Dalam Proses Kepailitan.}

Undang-Undang Kepailitan belum memberikan perlindungan kepada debitor, karena persyaratan permohonan pernyataan pailit memudahkan debitor dinyatakan

\footnotetext{
28 Ibid.

29 Munir Fuady, (2001), Op. cit., hlm.47.

30 Putusan Nomor 20/Pailit/2011/PN.Niaga.Sby, hlm.10.
} 
pailit, walaupun sebenarnya debitor dalam keadaan solven. ${ }^{31}$ Hal ini terjadi karena Undang-Undang Kepailitan Indonesia tidak berdasarkan filosofi yang melindungi kepentingan debitor solven namun mengalami kesulitan keuangan untuk terus melangsungkan kegiatan usahanya. ${ }^{32}$

Debitor dalam proses kepailitan memerlukan perlindungan hukum dan kepastian hukum. Perlindungan hukum menjadi kewajiban suatu negara, dan perlindungan hukum merupakan hak warganegara. Perlindungan hukum sebagai kumpulan peraturan atau kaidah yang akan dapat melindungi suatu hal dari hal lainnya. Perlindungan hukum terhadap debitor, berarti hukum memberikan perlindungan, sehingga persyaratan permohonan pernyataan pailit "tidak" memudahkan pailitnya debitor. ${ }^{33}$ Berdasarkan ketentuan Pasal 2 Ayat (1), Undang-Undanag No. 37 Tahun 2004 tentang Kepailitandan Kewajiban Pembayaran Utang yang selanjutnya disebut UU K dan PKPU. Permohonan pernyataan pailit dapat diajukan terhadap debitor yang mempunyai dua atau lebih kreditor dan tidak membayar lunas sedikitnya satu utang yang telah jatuh waktu dan dapat ditagih, dinyatakan pailit dengan putusan pengadilan. Ketentuan ini hanya mengacu kepada kewajiban dibidang bisnis atau seteidak-tidaknya menyangkut prihal kekayaan harta benda dengan berlandaskan ketidakmampuan debitor untuk membayar kewajibannya kepada kreditor, bukan ketidakmauan karena alasan wanprestasi

Lihat syarat pernyataan pailit dalam Pasal 2 ayat (1) Undang-Undang Nomor 37 Tahun 2004.

Siti Anisah, Op.Cit., hlm.419.

Cf. Siti Anisah, 2008, op.cit., hlm..43. dan dugaan pemalsuan surat-surat, penipuan dan penggelapan atau kompleksitas atau perkara tidak sumir. Ketentuan ini tidak menyinggung kebangkrutan sebagai alasan debitur tidak membayar utang, mengingat pengertian "tidak membayar" dapat berarti tidak dapat membayar atau tidak mau membayar. ${ }^{34}$ Dalam penjelasan Pasal 2 Ayat (1), tidak dijelaskan mengenai maksud dari frase "tidak membayar utang" tersebut, sehingga dengan demikian ketentuan pasal 2, Ayat (1) mengandung norma kabur yang dapat menimbulkan kerancuan dalam menilai keadaan debitur mana yang seharusnya diajukan permohonan pernyataan pailit. ${ }^{35}$

Untuk itu perlu penerapan beberapa ketentuan kepailitan yang telah dikembangkan di negara-negara lain barangkali perlu dilakukan oleh Indonesia, berdasarkan pemikiran SitiAnisah: pertama, tujuan dalam hukum kepailitan seharusnya termasuk meningkatkan nilai perusahaan atau setidaknya mempertahannkannya, dan tidak melikuidasi perusahaan yang masih memiliki kemempuan untuk membayar kewajibannya, Kedua, tujuan kepailitan melindungi para pihak yang tidak dapat melindungi diri mereka sendiri, mmelalui pemberian keleluasaan bagi debitor untuk emperbaiki kinerja perusahaan. Ketiga, pemberian kesempatan bagi debitor yang tidak dapat membayar utangnya untuk membuat suatu fresh start free dari semua utang yang membebani, asal saja debitor tidak melakukan perbuatan yang tidak jujur

\footnotetext{
Lihat Man S. Sastrawidjaja, 2010, op.cit., hlm.80.

Samuil Kurniawan Nyoman, 2013, op.cit., hlm.3
} 
atau perbuatan tidak patut lainnya yang berkaitan dengan masalah keuangan. ${ }^{36}$

Berdasarkan analisis penulis bahwa, UU Kepailitan pada masa yang akan datang memerlukan adanya insolvency test. Adapun alasannya: Pertama untuk mencegah debitor yang asetnya lebih banyak dibandingkan dengan utangnya dinyatakan pailit oleh pengadilan. Seseorang dianggap solven jika dan hanya jika orang tersebut dapat melunasi utangnya yang telah jatuh waktu dan dapat ditagih. Debitor juga dianggap solven apabila aset debitor tidak melebihi utangnya. Sebaliknya, seseorang yang tidak dapat membayar utangnya yang telah jatuh waktu dan dapat ditagih disebut dengan insolven. Secara garis besar terdapat tiga financial"test" untuk menentukan insolvensi. Pertama, "balance-sheet test". Kedua, "cash flow test" atau disebut juga dengan equity test. Ketiga, analisis transaksional. Analisis transaksional berlaku ketika perusahaan melakukan transaksi yang mengakibatkan permodalan perusahaan berkurang secara tidak rasional, dan perusahaan menhadapi risiko insolvensi yang tidak dapat diterima oleh akal sehat. Ketika hal itu terjadi, maka berdasarkan analisis transaksional perusahaan telah memasuki zona insolvensi. Meskipun terdapat tiga financial test, namun secara umum lebih banyak digunakan dua tes, yaitu balance sheet test dan equity atau cash flow test. ${ }^{37}$

Kedua, pengertian yang luas dalam UU Nomor 37 Tahun 2004 memerlukan pembuktian yang sederhana. Dalam praktik pengertian sederhana dalam UU

Siti Anisah, 2008, Perlindungan----, op.cit., hlm. 420. Siti Anisah, 2008, op.cit., hlm.421.
No 37 Tahun 2004 tentang Kepailitan dan PKPU dijadikan alasan untuk menolak permohonan pernyataan pailit oleh hakim pengadilan niaga dengan alasan permohonan pernyataan pailit yang diajukan memerlukan pembuktian yang tidak sederhana. Hal ini semakin mempertegas bahwa permohonan pernyataan pailit yang mensyaratkan dalam arti luas tidak dapat diselesaikan melalui mekanisme pembuktian sederhana. Demkian pula terhadap ketentuan-ketentuan lain seperti actio paulana, pembuktian kreditor fiktif, dan gugatan terhadap direksi yang menyebabkan perseroan pailit karena kelalaian atau kesalahannya, serta maupun penyalah gunaan wewenang oleh pemegang saham, pembuktiannyapun tidak sederhana. Demikian halnya dengan, kreditor yang melakukan wanprestasidan dugan penipuanpenipuan seperti dalam kasus kepailitan PT DAB yang dimohonkan pailit oleh PT Industama Karsa Mandiri, dari putusan Nomor: 20/Pailit/PN.Niaga.Sby. Untuk itu insolvensy test adalah alternatif yang tepat untuk menggantikan pembuktian yang sederhana dalam menentukan apakah debitor dapat dinyatakan pailit atau tidak. Ketika debitor mengajukan dirinya atau diajukan pihak lain untuk dinyatakan pailit ke pengadilan Niaga, maka pada saat itu hakim pengadilan niaga menetapkan dimulainya insolvensy test. ${ }^{38}$

Dalam konteks penelitian ini, teori kepastian hukum tidak hanya merupakan pasal-pasal dalam Undang-Undang semestinya dikaitkan dengan konsistensi putusan hakim yang satu dengan putusan

Ibid., hlm.422. 
hakim lainnya dalam kasus yang serupa yang telah diputuskan. ${ }^{39}$ Tampaknya, teori kepastian hukum dalam kasus permohonan pailit dari kreditor, tidak direspons oleh debitor, karena kreditor telah diduga sebagai pemohon pailit telah melakukan wanprestasi dan dugaan penipuan penipuan terhadap pihak termohon, ${ }^{40}$ karenanya pihak Termohon mengajukan Exceptio non adimpleti contractus. ${ }^{41}$ Pihak Termohon (Debitor) tidak mengajukan Penundaan kewajiban pembayaran utang atau PKPU sesuai dengan Undang-undang Nomor 37 Tahun 2004, Pasal 222 ayat (2, ) karena kepastian hukum tentang terjadi wanprestasi dan dugaan tindak pidana yang memerlukan pengujian di pengadilan.

Di sisi lain, perlindungan terhadap kepentingan kreditor semakin bertambah tegas dalam UU No. 37 Tahun 2004. Sebelum itupun, secara substantib baik faillssementsverordening maupun UU Nomor 4 Tahun 1998 adalah pro terhadap kepentingan kreditor. ${ }^{42}$ Pasal 222, Ayat $(1,2)$ UU No.37 Tahun 2004 Tentang K \& PKPU, tidak bermakna dan tidak mempunyai arti bagi debitor, Kreditor telah melakukan wanprestasi dalam Kontrek kerja, dan adanya dugaan penipuan-penipuan (Hal ini terkait dengan perjanjian dalam bentuk Surat Perintah Kerja (SPK) Nomor: 085/SPK/ BKR-MEP/VIII/2008 tertanggal 5 Agustus 2008 tidak dilaksanakan secara sempurna oleh kreditor (pemohon pailit). ${ }^{43}$

39 Peter Mahmud Marzuki, 2011, Pengantar Ilmu Hukum, Kencana, Jakarta, hlm.136-137.

40 Putusan Nomor : 20/Pailit/2011/PN.Niaga.Sby, hlm.8.

$41 \quad$ Ibid.

$42 \quad$ Siti Anisah, op. cit., hlm.497.

\subsection{Analisis Kasus}

Dalam hal kasus kepailitan Nomor 20/ Pailit/2011/PN.Niaga. Sby, sebelum kreditor (PT. Karsa Industama Mandiri) mengajukan permohonan pailit ke debitor (PT Dwimas Andalan Bali), supaya mengedepankan asas keadilan dalam menyelesaikan persoalan utang-piutangnya dengan debitor sebelum memutus untuk mempergunakan pranata kepailitan. Dalam memahami asas keadilan, tidak hanya diartikan keadilan sematamata dari tidak terbayarnya piutang dari kreditor, banyak persoalan yang ada dalam proses kepailitan yang semestinya harus dipertimbangakan oleh hakim secara berkeadilan sebelum memutus suatu perkara kepailitan. Semestinya majelis hakim mempertimbangkan bahwa termohon pailit telah mangajukan tangkisan bahwa pemohon pailit (PT KIM) telah wanprestasi, dan melakukan penipuan-penipuan, sehingga majelis hakim bisa dengan tepat meneliti, mengkaji, kasus permohonan ini dengan tepat, adil berdasarkan fakta hukum seperti dapat mempertimbangkan "tidak dapat menerima permohonan pailit" atau kata lain "dapat menolak permohonan pailit".

Permohonan pailit yang diajukan oleh kreditor PT Karsa Industama Mandiri kepada Debitor PT Dwimas Andalan Bali, bahwa pihak Termohon tidak memiliki utang yang jatuh tempo dan dapat ditagih oleh pihak pemohon, sebaliknya pihak pemohon telah melakukan wanprestasi dan penipuan-

43 Putusan Nomor 20/Pailit/2011.PN.Niaga.Sby., hlm.8-11. Tangkisan Termohon Pailit bahwa tidak dilaksanakan perjanjian secara sempurna, demikian pula Surat Perjanjian Pengakuan Utang Nomor 002/ SPPH/KIM-BKR/III/2009, merupakan rekapitulasi fiktif belaka. 
penipuanterhadappihaktermohon; karenanya pihak Termohon mengajukan exception non adimpleti contractus. ${ }^{44}$ Menurut M Sinaga mantan hakim Niaga, makna exception non adimpleti contractus bahwa pemohon pailit juga mempunyai utang kepada termohon pailit. Jadi antara pemohon dan termohon pailit saling mempunyai utang piutang. Dalam keadaan yang demikian maka kedua utang itu diperjumpakan (set-off). Dalam konteks yang demikian, termohon pailit dapat mengajukan eksepsi dengan dalil bahwa pemohon pailit juga mempunyai utang kepada termohon pailit, sehinnga perlu diperjumpakan utang tersebut. ${ }^{45}$ Perjumpaan utang atau kompensasi (set-off) adalah suatu peristiwa hukum yang terjadi demi hukum di antara orang yang mempunyai utang maupun piutang dengan Debitor Pailit sebelum putusan pailit diucapkan. Perjumpaan utang terjadi demi hukum sesuai dengan asas Ipso Iure Compensatur. ${ }^{46}$ Setelah putusan pailit diucapkan, semua utang piutang tidak dapat diperjumpakan (vide Pasal 51 ayat (1) UU Nomor 37 Tahun 2004 tentang K \& PKPU).

Menurut Syamsudin M Sinaga, alasan untuk mencegah kepailitan adalah dengan mengajukan permohonan PKPU, sebagai jawaban,tanggapan, tangkisan atau counter terhadap permohonan pailit. ${ }^{47}$

Alasan lain mengapa Debitor tidak mengajukan PKPU adalah karena Pemohon Pailit diduga telah melakukan tindak pidana pemalsuan surat dan menempatkan

44 Jawaban Termohon dalam Putusan No.20/Pailit/2011/ PN.Niaga.Sbya, hlm.8.

45 Syamsudin M.Sinaga,2012, Hukum Kepailitan Indonesia, PT. Tatanusa, Jakarta, hlm.111.

$46 \quad$ Ibid., hlm.121.

$47 \quad$ Ibid. hlm.111. keterangan palsu yang dilaporkan ke Polda Bali pada tanggal 26 Maret 2012, sesuai dengan laporan polisi Nomor LP/92/ III/2012 Bali/Dit. Reskrimum. ${ }^{48}$ Pendapat hakim, bahwa pada dasarnya Terlawan (PT. Dimas Andalan Bali) ingin menggunakan berbagai alasan dan cara untuk menghalangi dan atau untuk menggugurkan kepailitan tersebut sehingga pada tanggal 26 Maret, membuat laporan Pidana pemalsuan surat dan menempatkan keterangan palsu di Kepolisian Daerah Bali, sesuai dengan laporan Polisi Nomor LP/92/III/2012/Bali/ Dit.Reskrimum. ${ }^{49}$

Seyogyanya hakim dapat memperjumpakan utang-piutang sebelum memutus sidang kepailitan dengan putusan Pailit, Selain itu, berdasarakan Pasal 8 ayat (4) Permohonan pernyataan Pailit harus dikabulkan apabila terdapat fakta atau keadaan yang terbukti secara sederhana bahwa persyaratan untuk dinyatakan pailit sebagaimana dimaksud Pasal 2 Ayat (1) UU Kepailitan dan PKPU Nomor; 37 Tahun 2004. Dalam hal ini, pemohon Pailit telah Wanprestasi sehingga diajukan Exceptio non Adimpleti contractus ${ }^{50}$ serta ada dugaan terjadinya penipuan-penipuan dalam proses perkara kepailitan. Menurut penulis perkara kepailitan Nomor 20/|Pailit/2011/PN.Niaga. Sby adalah "complicated” (tidak sederhana). Menurut Termohon, bahwa sama sekali tidak mempunyai kewajiban yang jatuh tempo dan dapat ditagih oleh pihak pemohon,

\footnotetext{
48 Lihat Putusan Nomor: 103 PK/Pdt.Sus-Pailit/2013, hlm.3.

49 Ibid.

50 Putusan Pengadilan Niaga Nomor: 20/Pailit/2011/ PN.Niaga.Sby, hlm.17.
} 
karena hingga saat ini, pihak pemohon telah lalai melakukan kewajibannya terhadap pihak Termohon sehingga saat ini kewajiban pihak Termohon sehingga saat ini kewajiban pihak Termohon belum terbit (secara sederhana dapat dikatakan bahwa tidak ada utang/kewajiban yang jatuh tempo dan dapat ditagih). ${ }^{51}$

\section{SIMPULAN DAN SARAN}

\section{Simpulan}

1. Mekanisme dalam kepailitan debitor mempunyai hak untuk mengajukan PKPU sesuai dengan Pasal 222 Ayat (2) UUK \& PKPU, dengan melakukan perdamaiandengan seluruh kreditornya dan melakukan restrukturisasi utang. Oleh Debitor, hal ini tidak dilakukan karena kreditor (PT KIM) pemohon pailit telah melakukan wanprestasi dalam kontrak kerja dan dugaan melakukan penipuan-penipuan. Adaya dugaan Kreditor melakukan penipuanpenipuan dan pemalsuan surat-surat oleh kreditor, sehingga dilaporkan ke Polda Bali. Kemudian pertimbangan hakim bahwa dalam proses kepailitan, tidak ada perdamaian yang dapat dilakukan sebelum ada putusan, yang dimungkinkan adalah pihak Temohon untuk menghindari pernyataan pailit. Semestinya Termohon pailit pada kesempatan pertama mengajukan penawaran perdamaian dengan cara mengajukan PKPU, dengan prinsip bahwa penawaran perdamaian ditujukan kepada seluruh kreditor. Selain itu, pendapat Majelis hakim mempailitkan Debitor (PT Dwimas Andalan Bali) adalah Termohon pailit ingin mempergunakan berbagai alasan dan cara untuk menghalangi dan /atau untuk menggugurkan kepailitan.

2. Dalam hukum kepailitan Indonesia, debitor sangat rentan dimohonkan pailit sebagai alat untuk menagih utang oleh kreditor-kreditornya. Undang-undang Kepailitan tidak berdasarkan filosofi yang melindungi kepentingan debitor solven, namun mengalami kesulitan keuangan untuk terus melangsungkan kegiatan usahanya. UU Kepailitan dapat menjadi alat social politik, dan kebijakan ekonomi dan tidak hanya untuk menyelesaikan masalah utangpiutang antara debitor dan kreditor serta membagi harta pailit kepada para kreditor. Debitor seharusnya diberikan kewenangan penuh untuk tetap menguasai perusahaan selama PKPU berlangsung. Pengangkatan pengurus yang professional baru dilakukan oleh pengadilan Niaga apabila terbukti debitor tidak mampu melaksanakan pengurusan terhadap perusahaannya dengan baik.

\section{Saran}

1. Berkenaan dengan tidak bermaknanya PKPU dalam proses kepailitan yang mengandung wanprestasi dan dugaan penipuan-penipuan perlu adanya pertimbangan yang holistic dan komprehensif dalam menegakkan keadilan dan kepastian hukum 
sebelum mengambil putusan pailit, perlu kiranya memperhatikan berbagai aspek dalam penerapannya maka PKPU dan kepailitan dalam hal adanya persoalan perdata dan pidana dalam kepailitan hakim harus Diharapkan Majelis hakim dapat menerapkan hukum kepailitan dengan memilah dan memilih secara jelas perkara-perkara mana yang diselesaikan dengan hukum kepailitan, karena kepailitan berkaitan dengan ultimum remedium.

2. Perlu adanya revisi UU kepailitan yang berkaitan dengan debitor solven dan perlu adanya perlindungan terhadap debitor yang beritikad baik serta perlu adanya insolvensy test terhadap debitor.

\section{DAFTAR PUSTAKA}

\section{Buku}

Anton Suyatno, R, 2012, Pemanfaatan Penundaan kewajiban pembayaran Utang. Sebagai Upaya mencegah Kepailitan, Kencana Prenada Media Group.

Bernard L Tanya, dkk,2010, Teori Hukum

Strategi Tertib Manusia Lintas Ruang dan Generasi, Yogyakarta, Genta Publising.

Syamsudin M.Sinaga,2012, Hukum

Kepailitan Indonesia, PT. Tatanusa, Jakarta

Samuil Kurniawan Nyoman, 2013, "Kepailitan Yang bermula dari keadaan Exceptio inadimpleti Contractus (Alanisis terhadap Putusan Pernyataan pailit dalam Perspektif Hukum Perjanjian dan Kepailitan)",
Dalam Tesis yang belum diterbitkan, Denpasar, Program Studi Magister(S2) ilmu hukum Program Pasca Sarjana Universitas Udayana, Denpasar.

Siti Anisah, 2008, Perlindungan Kepentingan Kreditor dan Debitor dalam Hukum Kepailitan di Indonesia, Studi PutusanPutusan Pengadilan, Jakarta, Total Media Peter Mahmud Marzuki, 2011, Pengantar Ilmu Hukum, Kencana, Jakarta.

Man S. Sastrawidjaja, 2010, Hukum Kepailitan dan Penundaan kewajiban pembayaran Utang, Alumni, Bandung, Munir Fuady, (2001), Hukum Kontrak (Dari Sudut Pandang Hukum Bisnis), Bandung, PT Citra Aditya Bakti,

\section{Internet}

Bali Tribune, 2012, Awas Sindikat Pemailitan, http://koranbalitribune. com.hlm.9. diakses tanggal 21 Agustus 2014.

\section{Sumber Hukum Priimeir}

UU Nomor 37 Tahun 2004 Tentang Kepailitan dan Penundaan Kewajiban pembayaran Utang

Putusan Pengadilan Niaga Nomor: 20/ Pailit/2011/PN.Niaga.Sby.

Putusan Mahkamah Agung Nomor: 103 PK/ Pdt.Sus-Pailit/2013

Salinan Putusan Nomor: 692/K/Pdt. Sus/2011, tertanggal 21 Desember 2011.

\section{Biodata Penulis:}

Nama : I Wayan Wesna Astara Alamat : Jl. Nusantara No. 8 TubanKuta Kabupaten Badung.

Telp/HP : : (0361) 753478/ 08123904581

E-mail : :wesna astara@yahoo.com 